\title{
Ethnicity in Space and Everyday Practice: an Outline of a General Framework with Examples from New Mexico
}

\author{
PŘEMYSL MÁCHA
}

Department of Human Geography

University of Ostrava, Ostrava, Czech Republic

premysl.macha@osu.cz

\begin{abstract}
Studies of ethnicity have emphasized ethnicity's social, processual and event-like character. While they have been very successful in explaining change, they have failed to account for the durability and renewed importance of many group identities. We argue that taking into account spatial and embodied dimensions of ethnicity, we can explain continuity without falling back to primordialism and essentialism. The most important spatial factors in explaining the strength of ethnic identities include spatial separation, the built environment, generative processes associated with the built environment, performances and embodied practices, and the linguistic landscape. The article provides an outline for a general framework for the analysis of ethnicity, using examples from New Mexico as illustrations of individual arguments.
\end{abstract}

KEY WORDS: ethnicity, identity, space, place, landscape, built environment, embodiment, language

One of the important recent developments in the social sciences in general, and cultural geography and anthropology in particular, is a movement from text, representation and discourse to materiality and (embodied) practice. This development includes, for example, 
actor-network theory (LATOUR 2005), non-representational theory (THRIFT 2007), and post-phenomenology (INGOLD, WILEY), to name the most influential paradigms. What the different approaches within this new paradigm share is an interest in how social phenomena such as ethnicity in our case arise from our everyday physical involvements with the world and its various occupants. In other words, how these phenomena are done and made. Done in terms of (habitual) embodied practices, interactions and spatial performances and made in terms of the production of things, boundaries, places, and landscapes. The focus is less on the results and more on the processes which lead to them. The world is seen as being in an incessant process of becoming and so it is this (everyday) doing and making, the intentional and unintentional mingling and co-constitution of ideas, bodies, things and events, that comes to the fore in contemporary geographical and anthropological inquiry.

One of the fundamental issues in these new approaches is the experience of alterity, as compared to its simple representation and discursive analysis prevalent in previous approaches (ASH - SIMPSON 2016). Alterity is not only conceptualized, imagined and represented, but it is also done and made - established, communicated, and produced in everyday encounters and activities. Some of these activities are more habitual than others and some are associated with more tangible spatial constellations than others; all of them, however, quite literally take place. That is, they happen in space with spatial antecedents and spatial consequences.

Fredrik Barth, one of the most influential theorist of ethnicity, argued (BARTH 1969:15) that ethnic boundaries (for which the establishment of the Other is a fundamental starting point) are primarily social, though they may have spatial counterparts. In view of the aforementioned, however, I would like to argue that ethnic boundaries are equally spatial as they are social and that the two cannot be analytically separated. For this reason, I prefer to use the term "socio-spatial" to emphasize the double character of the phenomena we study.

Space is a necessary component of social research (MASSEY 2007). Historically, however, more attention in research on ethnicity and nationalism has been focused on the social than the spatial. We know a lot about how ethnic and national boundaries are socially (politically, economically, legislatively) created, maintained and challenged, but we know considerably less about the spaces of ethnicity at different scales and the role of space in everyday ethnic relations. Thanks to the writings of Barth and other influential theorists of ethnicity and nationalism such as Eriksen (2002) or Brubaker (2003) we know now that ethnicity is relational and situational and arises only under specific conditions. It is an event rather than a fixed attribute of a person or a group. For this reason, ethnic identification is 
potentially very dynamic and flexible, changing from context to context and from individual to individual. However, while this is true, it is also true that many group identities show a remarkable degree of continuity and stability which cannot be explained simply socially without falling back into some type of the long-discredited essentialism and primordialism. The challenge then is to explain continuity without reifying or naturalizing groups.

The answer is provided by the new approaches in cultural geography and anthropology mentioned above. As Latour (2005) shows, it is the materiality of our social life that serves as its primary stabilizing force. Without things social life as we know it would be impossible. According to Ingold (2015), humans are defined by their productive activities mingling with their environments and giving human life form and purpose. As Ingold says, "to human is a verb" (Ibid 115). And Thrift (2007) stresses the affective bodily interactions before and beyond representations whereby individual and collective action is realized. In relation to ethnicity, then, it is its embodied material, productive and spatial character which stabilizes it and turns it into such a powerful and difficult-to-eradicate feature of contemporary world. Yet, a comprehensive analytical framework for its study has not yet been developed. In this article, we would therefore like to lay out a preliminary outline for such a general framework. Its further empirical testing and fine-tuning will allow for a complex analysis of ethnicity as a spatial, material and embodied phenomenon.

Examples cited are drawn primarily from my long-term interest in the ethnic processes in New Mexico. This state is located in the southwestern USA where different groups of indigenous people, Spanish, Mexican and Anglo settlers, as well as recent Latino immigrants have interacted over time to produce a complicated ethnic landscape in which it is not easy to navigate. This landscape provides numerous examples of how ethnic boundaries are produced, maintained and subverted socio-spatially. However, we would not like to suggest that New Mexico is somehow exceptional. Actually, if the outline of our framework is adequate, it should allow for analogical empirical studies anywhere in the world, regardless of the seeming or proclaimed ethnic homogeneity of the area. We hope such studies will emerge rapidly.

\section{The Socio-Spatial Production of Ethnic Boundaries}

The principal (semi-)stable component of ethnic relations which persists over time - in spite of a constant change in the composition and everyday cultural practices of the group is the ethnic boundary. According to Barth, it is THE defining feature of ethnicity. From a geographical perspective on ethnicity it follows that the critical object of analysis should be 
the (socio-)spatial production and negotiation of ethnic boundaries - how they are done and made. So how is ethnicity done and made spatially? There are several strategies or processes by which ethnicity is embedded in the everyday life. Through them, it becomes generally accepted, internalized and habituated to the extent that it begins to look natural and inevitable, an incontrovertible fact of life with which nothing can be done, a natural part of the social order. Even though any thinkable list of these spatial strategies would most likely be incomplete, I believe the most important of them are the following:

a) spatial segregation at different scales (frontiers, international borders, national state borders, provinces, regions, villages, urban neighborhoods)

b) manipulation of the built environment (buildings, roads, landscape features, urban planning)

c) differentiation of generative processes (building, making, irrigating, maintenance)

d) differential spatial regimes (access, discipline, inclusion, exclusion)

e) banal and spectacular performances (embodiment)

f) linguistic appropriation and signification of space (signs, place names)

Each of these is highly complex in itself and would deserve a separate article (or even a book). Some have already been repeatedly addressed in different case studies while others still wait for a detailed analysis. However, we are not aware of any exhaustive treatment of ethnicity as a spatial phenomenon that would incorporate all of them. What follows is a brief outline of what such an analysis could look like.

\section{Spatial segregation}

The first factor or strategy is spatial segregation at different scales - state, provincial, regional, and local. Much attention, especially in political and cultural geography, has been paid to state borders and their impact upon people and their self-understanding (see e.g. NEWMAN - PAASI 1998; VAN HOUTUM - KRAMSCH - ZIERHOFER 2005; AMOORE 2006, PRESCOTT 2014). The current migration crisis in Europe has rematerialized state borders quite extensively - we have seen the rise of new fences, walls, gates, buildings, and border controls with all the associated border paraphernalia and performances. But even without this rematerialization, borders structure peoples' lives as 

from New Mexico

effectively albeit more subtly contributing thus to the naturalization and internalization of group boundaries.

In the context of our area of research, it is the U.S.-Mexico state border that has historically had a dramatic impact on the development of ethnic landscapes on both sides of the border, with profound consequences reaching deep into the interior of both states and shaping their domestic and international political engagements (see e.g. ROMERO 2008; JOHN 2011). The great paradox of borders is that they not only divide and separate but also join and connect (ALVAREZ 2012). It is the differential permeability of the border that makes it so important in ethnic and national relations.

In New Mexico, the impact has been complex. For one, the official establishment of the state border in 1848 turned the local Mexicans into "foreigners in their native land" (WEBER 2003). But even before its creation it generated a series of identity adaptations of different groups living in the territory (RESÉNDEZ 2005). As a consequence, it completely transformed the existing ethnic hierarchy and turned the previously dominant group - the Spanish-speaking Mejicanos - into a subordinated group, secondary to the AngloAmericans. In addition, it dramatically changed the situation for Native American communities and differently so for different groups. Whereas the nomadic Navajos, Apaches, Comanches and Utes were forced onto Indian reservations away from their traditional homelands, the Puebloans stayed in their villages but were not given Native American legal status. To obtain it, they had to fight for it. In spite of the dramatic impact of U.S. annexation in 1846, the core Pueblo-Hispano area has remained relatively stable while nomadic Native American groups have been mostly replaced by Anglos with the sole exception of the Navajos.

A fascinating issue in itself is the concept of the frontier, as differentiated from the border. The area of our research was a frontier region for centuries and it was characterized by territorial advances and losses, shifting loyalties and mixing of languages, religions and traditions (see e.g. JOHN 1996; BROOKS 2011; KESSELL 2013). The resulting ethnic landscape was and still is highly complex due to this frontier history to which the establishment of the national border added yet another dimension.

A separate topic is the establishment of the federal state borders - the carving out of New Mexico vis-à-vis Arizona, Colorado, Oklahoma and Texas. Especially Texas had a very conflictual relationship with the territory of New Mexico, particularly in the southeastern part popularly referred to as Little Texas. 
Within states, ethnic segregation can be seen at provincial, regional, county, and local levels as well, and it is, of course, significantly more common than segregation by state borders. This is, indeed, one of the most researched topics in cultural and regional geography and anthropology and is to a great extent as old as these disciplines. Spatial separation is not, however, "natural". It is the result of past decisions and current agendas. And so it has been in New Mexico - from establishing Spanish settlements side by side, but never inside, Pueblo communities to maintaining a sharp distinction between the settled and the nomadic populations to removing the in-between genizaro $^{l}$ groups from the ethnic core to the colonial peripheries as buffer zones to safe-guarding ethnic purity by promoting the construction of Anglo towns and neighborhoods outside the Hispano and Pueblo heartland (see e.g MEINIG 1971). The consequence is a persisting ethnic geography of the state only partially rewritten by latest migration flows and holding equally at the macro- (e.g. NOSTRAND 1996; GONZALES 2014), meso- (e.g. RODRÍGUEZ 2006) or micro-level including the urban neighborhoods in Albuquerque (see e.g. DURÁN 2007).

Since borders, frontiers and boundaries carve out ethnic homelands physically and mentally, they channel individual activities and projects and thus support their internalization and physical bodily habituation (walking along borders, visiting boundary markers, checking fences, preferential realization of activities within boundaries, etc.). As Ingold (2011:145-155) pointed out at a more general level, boundaries are more or less blurred lines that are walked through the environment and walked into our bodies and minds. Thus they give rise to places delimited and defined by them. In our case, these places are ethnic places and the boundaries are ethnic boundaries and their seeming stability depends on the inertia of the built environment (see below) but also on habitual repetitive activities along those lines. In this sense, boundaries are not simple "lines in the sand" (JOHN 2011).

To sum up, spatial segregation is a very important factor in stabilizing and naturalizing ethnic boundaries. It operates at different levels in association with different types of borders and frontiers, ranging from the official national borders to the informal but equally important "borders" of individual neighborhoods in a city. These levels are not independent but co-evolve and influence each other and together produce a complex ethnic landscape.

In the New Mexican context, the term genizaro refers to the descendants of Indian captives and mestizos. It is derived from the originally Turkish term for slave soldiers - janissary. 


\section{The built environment}

The second principal spatial factor in the naturalization of ethnicity is the built environment. At a general level, there is a strong relationship between power and architecture. As Dovey (1999:2) argues:

"Most people, most of the time, take the built environment for granted. This relegation of built form to the unquestioned frame is the key to its relations to power. The more that the structures and representations of power can be embedded in the framework of everyday life, the less questionable they become and the more effectively they can work. This is what lends built form a prime role as ideology. It is what Bourdieu calls the 'complicitous silence' of place as a framework to life that is the source of its deepest associations with power."

Ethnic relations always are, above all, relations of power. Ethnic boundaries serve to exclude those who are outside and to discipline those who want to - or are forced to - stay within them. We can therefore fruitfully apply Dovey's general framework to demonstrate the ethnic use of the built environment. Just as architecture naturalizes relations of power it also naturalizes ethnicity and embeds it in the spaces of our everyday lives:

"Places symbolize socially constructed identities and differences - of persons, cultures, institutions and nations. The politics of identity and difference is mediated in an arena of spatial representation and the inertia of buildings can 'fix' identity over time" (Ibid 16).

How is this accomplished? Dovey (Ibid 10-14) calls these architectural principles as force, coercion, manipulation, seduction, and authority, each with the associated set of architectural and urban designs. Force, for example, relies on walls, fences, gates, and general spatial confinement, coercion uses the threat of force to elicit spatial conformity, and manipulation channels the flow of people in such a way that the power exercised over them is kept invisible. I will not go into further detail, suffice it to say that there are many options architects and urban planners have when designing a building, a neighborhood or a city, and power, including ethnic power, finds expression in their work.

A number of books and articles have been written about the architecture and landscape in New Mexico. The vast majority of them, however, are simply descriptive and rather romanticizing. Written in the spirit of Paul Vidal de la Blache and following in the footsteps of Carl O. Sauer, they sought to identify the genius loci, i.e. the spirit of place characteristic of New Mexico. They mostly found it in "ageless adobe", to paraphrase one of the many books on this topic (IOWA 1985; see also BUNTING 1976, JACKSON 1985; SCULLY 1989) referring to the mud-brick, mud-plastered buildings with protruding 

from New Mexico

wooden vigas harmoniously placed in the desert environment and associated with the Hispanic and Pueblo communities in the state, which were idealized as timeless, unchanging and spiritually connected with the land

Only in the recent decades have we had the opportunity to appreciate sufficiently the complex architectural politics shaping the New Mexican landscape and the cultural exchanges, adaptations, and inventions accompanying this process (see e.g. MARKOVICH - PREISER - STURM 1990; MORROW - PRICE 1997; WILSON 1997). These studies document the architectural and spatial decisions made by ethnic politicians in order to build a strong ethnic identity with a clearly defined boundary in different times and places. Examples include Anasazi differentiation in pre-Columbian times, Pueblo-Navaho, PuebloSpanish, and Spanish-Anglo ${ }^{2}$ architectural exchanges as well as the rise of the Pueblorevival/Santa Fe style as a hegemonic tool for the construction of the Anglo-controlled New Mexican state identity (see e.g. MÁCHA 2013).

Now, as with spatial separation, the impact of the built environment can be analyzed at different scales - region, community and individual buildings. In New Mexico, at the regional level, there are at least two fundamental human forces which - in addition to natural geomorphological features - help to construct ethnic boundaries. One is the spatial geometry of land division. In New Mexico, the square "grid" of the Anglo-American township-and-range survey had to respect older land divisions which were partly organic, respecting natural features such as mountain ranges and rivers, and partly legally established in the form of communal land grants (mercedes reales). From a bird's-eye view, the New Mexican landscape is a mixture of spatial geometries supported by the built environment (walls, fences, roads, different land management regimes) that closely correlate with ethnic boundaries. Indeed, it is a land ownership largely determined by the geometry of land division that is, together with water rights, the greatest source of ethnic conflict in New Mexico (see e.g. DUNBAR - ORTIZ 2007; CORREIA 2013).

The other crucial regional factor unique to New Mexico is the construction of irrigation ditches. Agriculture is very difficult without irrigation and so irrigation ditches are the backbones of Hispanic urban planning. Pueblo villages were mostly built before the arrival of the Spanish who brought large scale irrigation with them while Anglo towns were built

2 In New Mexico, the term "Anglo" is a clearly defined ethnic category referring to anyone of nonHispanic European origin. It is a common term without a pejorative meaning and it is widely used in ordinary conversations.

DOI: 10.1515/eas-2017-0007 C University of SS. Cyril and Methodius in Trnava. All rights reserved. 
PŘEMYSL MÁCHA

Ethnicity in Space and Everyday Practice: an Outline of a General Framework with Examples from New Mexico

either as industrial and commercial centers which did not depend on irrigation or they used underground water. Irrigation ditches following natural landscape contours thus give form to Hispanic settlements but because of water scarcity and conflicts over water rights they also function as a crucial element in the ethnic relations of the state (see e.g. RIVERA 1999; RODRÍGUEZ 2006).

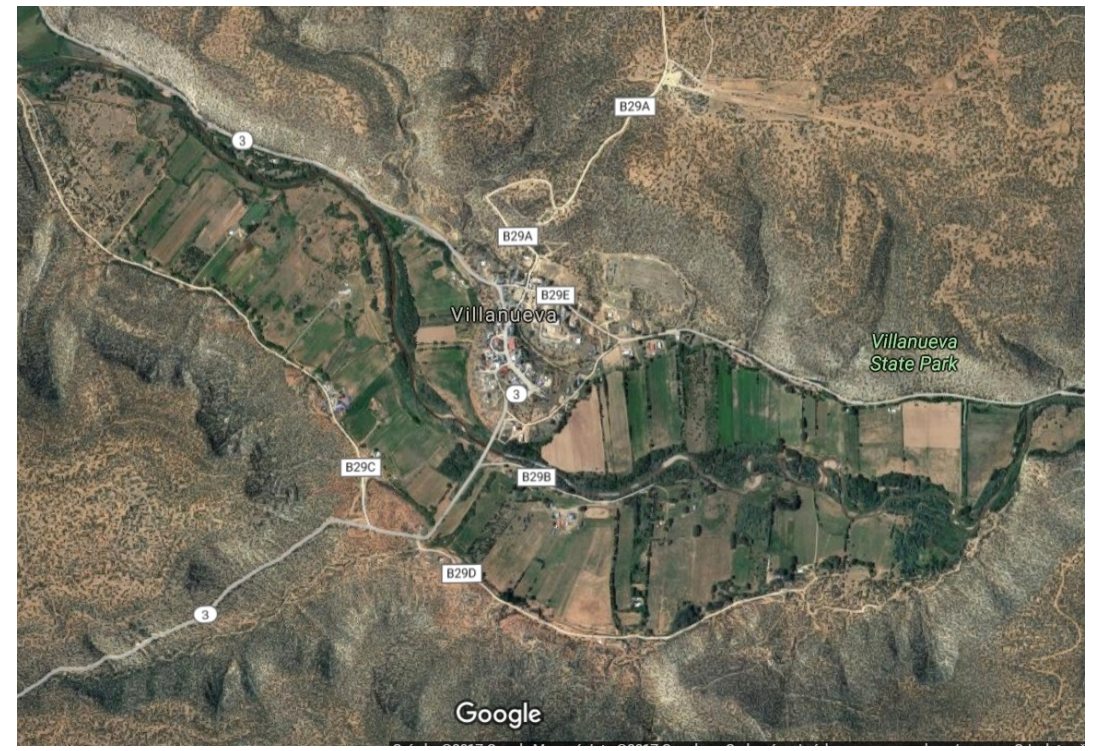

Figure 1: The Hispanic village of Villanueva organically adjusts to the geomorphology and the acequia irrigation system. Source: Google Maps, 2017. 


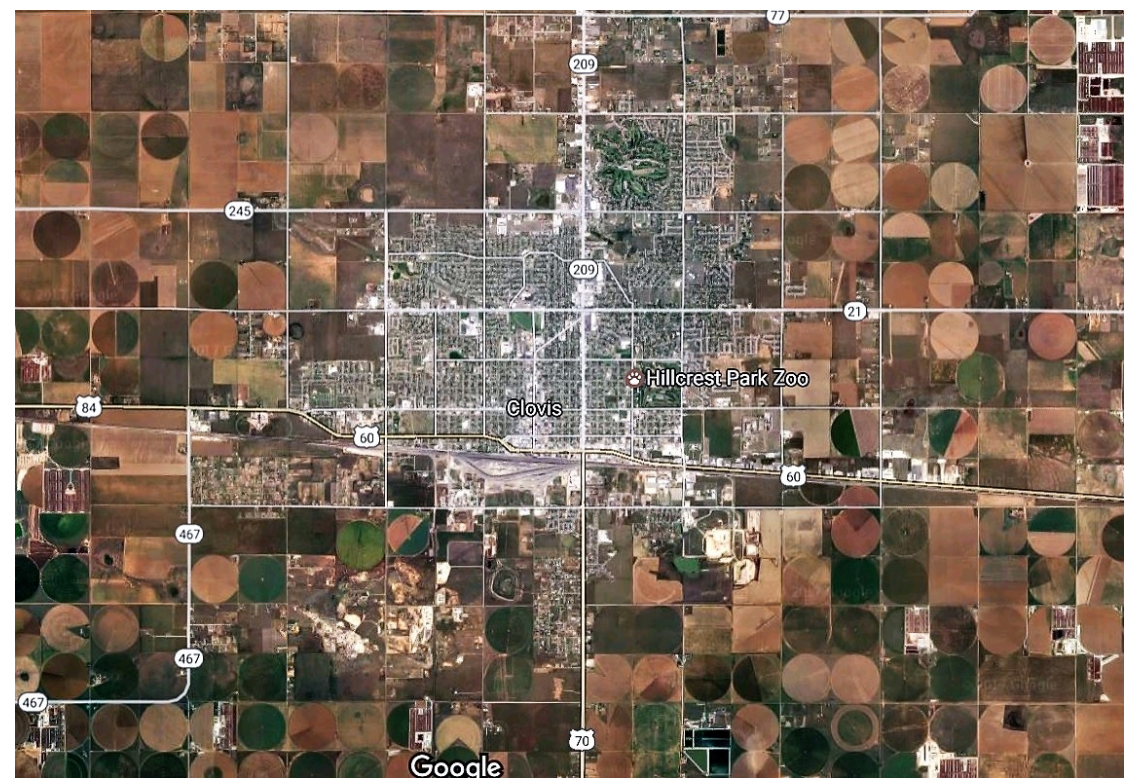

Figure 2: The Anglo town of Clovis uses the square grid to divide the land into regular sections irrigated by wells. Source: Google Maps, 2017.

At the community level, what immediately strikes the eye is the difference in urban design between Pueblo/Hispanic and Anglo settlements. The central focus of community life in Pueblo and Hispanic villages in New Mexico is the plaza. Studies in Wilson and Polyzoides (2011) document the architectural richness of New Mexican plazas as well as their crucial role in the daily life of Pueblo and Hispanic communities. This is in sharp contrast with the Anglo approach to town planning, centered around the main street. Where Pueblo and Hispanic communities are centripetal and closed, the Anglo town is centrifugal and open. This difference in urban design is, for example, still clearly visible in the urban lay-out and ethnic composition of Albuquerque with the original Hispanic Old Town standing apart from the Anglo part of town historically built around main street (Route 66) and the railroad. The same holds true for other towns in the state such as Las Vegas and Santa Fe.

At the level of individual buildings, be they residential, public or religious, the architectural politics becomes even more pronounced and it goes well beyond the scope of this article to go into any kind of detail. No systematic study of the ethnic dimension of individual buildings in New Mexico has been published yet, but some indigenous public buildings 
were analyzed in Krinsky (1996) and Malnar and Vodvarka (2013) while Wilson (1997) and Hooker (2000) analyzed selected buildings in Santa Fe and Albuquerque. Suffice it to say that structures in New Mexico as diverse as stone shrines, chapels, kivas ${ }^{3}$, moradas ${ }^{4}$, churches, private homes, barns, shops, schools, public buildings, bridges, and casinos all manifest differing degrees of ethnic membership and help to reinforce ethnic boundaries. As a consequence, we find numerous cases where architectural form, exterior decoration and landscaping of the immediate surroundings combine to produce an ethnic message which delimits group membership. These examples include e.g. the use of the traditional Navaho house ("hogan") as an inspiration for buildings as diverse as a juvenile correction facility, Catholic church, water tank, Navaho council chamber and modern private residences. Other examples include cultural centers and public buildings in Puebloan communities built in the form of traditional buildings, simulating their outward appearance while housing modern interiors and being built from modern materials. The most dramatic impact upon the ethnic landscape of New Mexico has had the rise of the Anglo-dominated Pueblo Revival/Santa Fe style which has appropriated traditional architectural forms to promote a common state identity and suppress the rich architectural history of the state by forcibly remodeling older buildings and imposing strict building codes on any new construction. The city of Santa Fe is a tragic example of this ethnic process (see WILSON 1997). Another culmination of this effort is the New Mexico state capitol built in the form of a Puebloan kiva, plastered with mud-like plaster to resemble Hispanic buildings and crowned with a row of bricks and Neo-Classical porticos in the so-called New Mexico territorial style produced by the U.S. military after the occupation of New Mexico. The ethnic hierarchy and the ethnic message are clear.

$3 \quad$ Kiva is the most important and most sacred religious structure in Pueblo communities. Some are circular, others rectangular, and all are accessed by a ladder through an opening in the roof.

$4 \quad$ Morada is a meeting house for Hispanic religious brotherhoods (hermanos penitentes). It has a chapel for prayers, a meeting room and a room for secret rituals. Moradas are unique to Hispanic villages in New Mexico.

DOI: 10.1515/eas-2017-0007 C University of SS. Cyril and Methodius in Trnava. All rights reserved. 
PŘEMYSL MÁCHA

Ethnicity in Space and Everyday Practice: an Outline of a General Framework with Examples from New Mexico

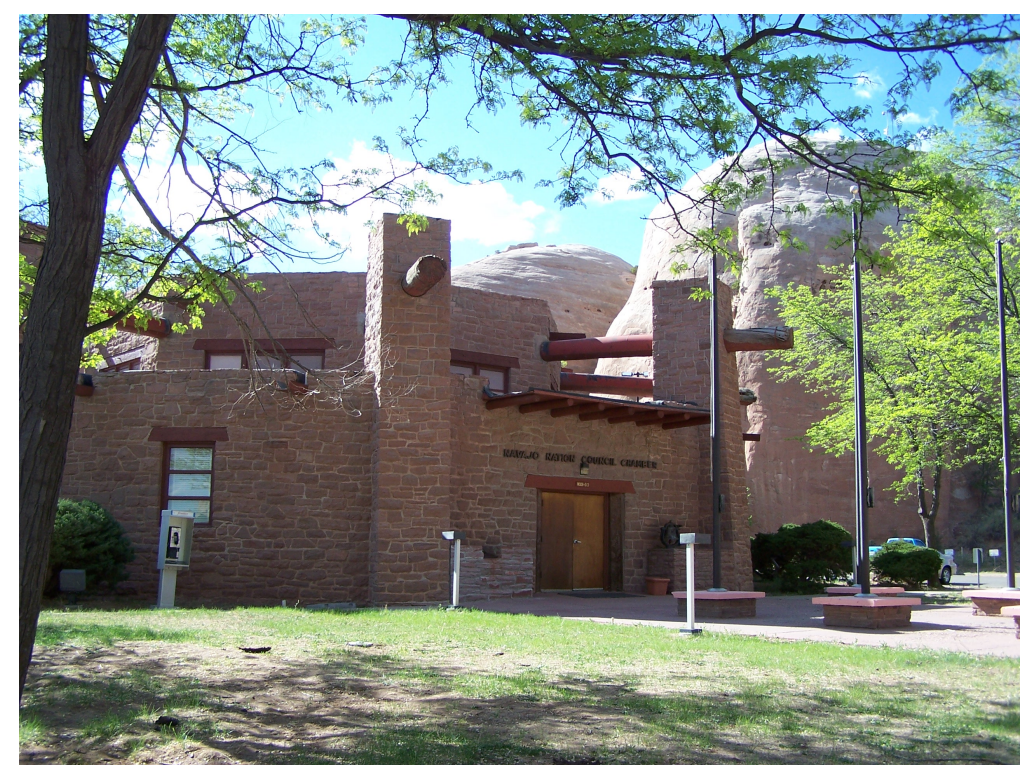

Figure 3: Navaho Nation Council Chamber in Window Rock built in the form of a traditional Navaho home - a Hogan. Photo: P. Mácha 2006.

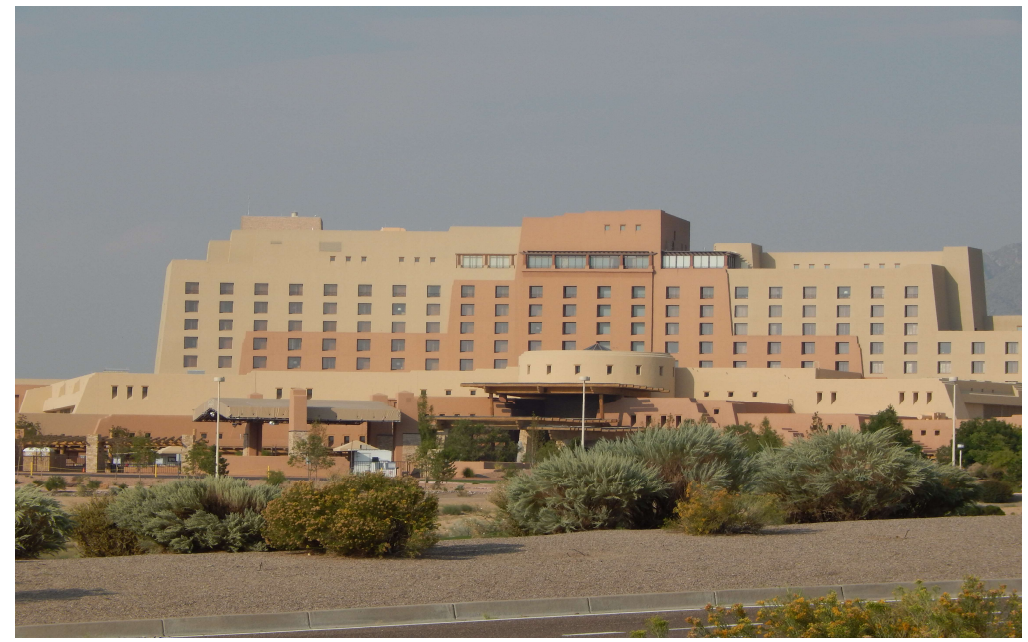

Figure 4: Sandia Pueblo casino built in the shape of the pueblos's sacred mountain. Photo: P. Mácha 2015. 
PŘEMYSL MÁCHA

Ethnicity in Space and Everyday Practice: an Outline of a General Framework with Examples from New Mexico

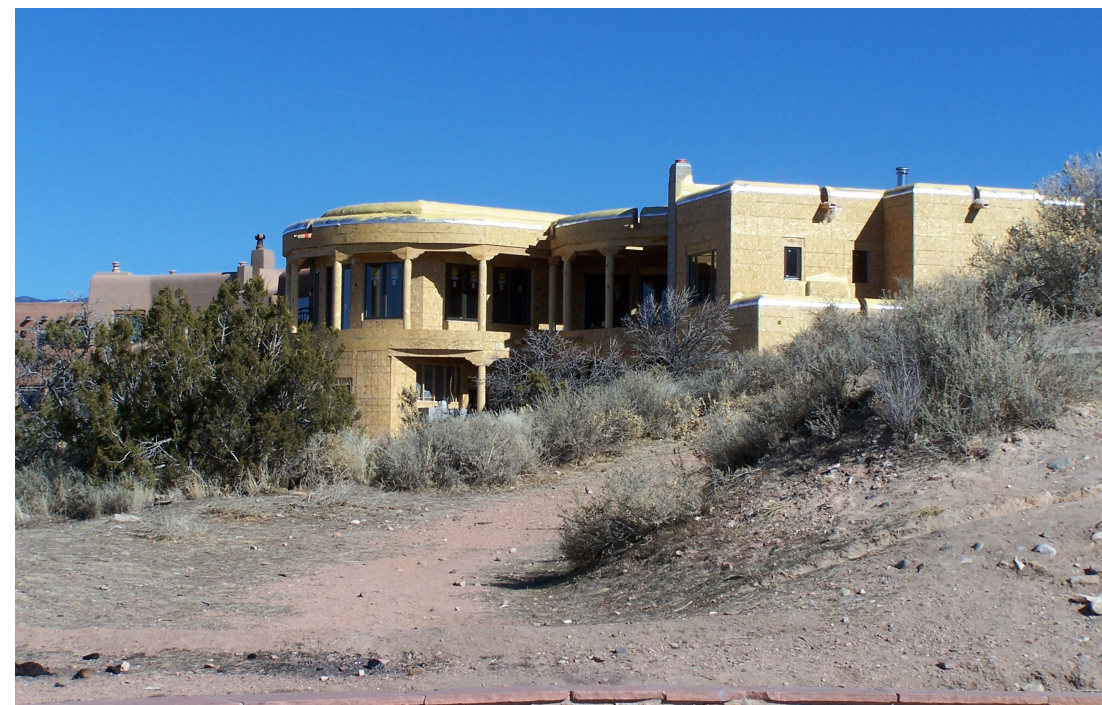

Figure 5: Fake adobe house in the so-called Santa Fe Style before plastering, Santa Fe. Photo: P. Mácha 2006.

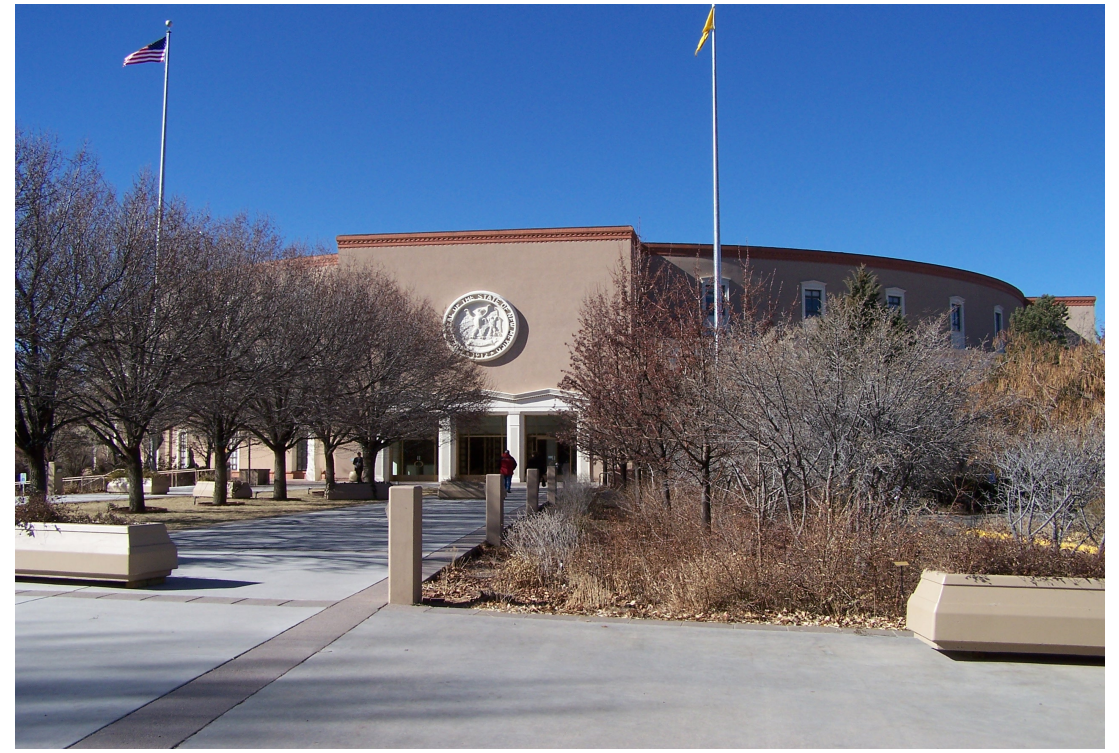

Figure 6: New Mexico State Capitol built in the Territorial Style with Hispanic and Pueblo elements as an expresison of a common state identity with a clear ethnic hierarchy. Photo: P. Mácha 2006. 


\section{Generative processes}

The third factor involves the (re-) generative processes which are closely associated with the production and maintenance of the ethnically defined built environment. While the built environment is crucial in itself for channeling social life and giving it a particular spatial form, the individual structures have a life of their own, from coming into being to everyday use and maintenance to their eventual disappearance or transformation. And the social life associated with individual structures is equally important to the internalization of ethnic boundaries as the structures themselves.

Any new construction or rehabilitation of old structures requires a host of decisions which may or may not impact on ethnic relations. Architectural styles, planners, architects, contractors, staff, maintenance personnel etc. have to be chosen and this choice often follows ethnic lines. For example, in the case of the recent rehabilitation of the old center of Ohkay Owingeh Pueblo, our interviews with representatives of the tribe and the architectural firm which provided the blueprints showed that the entire process from initial conceptual discussions to the rehabilitation of individual residential buildings and their transfer to their owners was tightly controlled by the tribal council and a special group of tribal elders who made the final decisions on all aspects of the rehabilitation process including the preferred architectural styles which were to express community values (see also e.g. Karaim 2015). The old center of Ohkay Owingeh has come back to life as an expression of an ethnic community and the process which led to this success was its decisive factor, as important as the built environment which it produced.

While major construction works are procedurally important for the establishment and maintenance of group boundaries, the regular up-keep of existing structures with communal importance also plays a significant role. Of particular interest in New Mexico is the regular maintenance of churches and irrigation ditches. Adobe churches have to be replastered annually and traditionally this has been the task of women. In order to remain functional, irrigation ditches have to be cleaned annually as well and this has traditionally been the task of men. Both women and men then annually take part in communal work which brings them together and differentiates them from the "outsiders". This example demonstrates how architecture and man-made landscape features structure not only the space but also the social life of the community. 


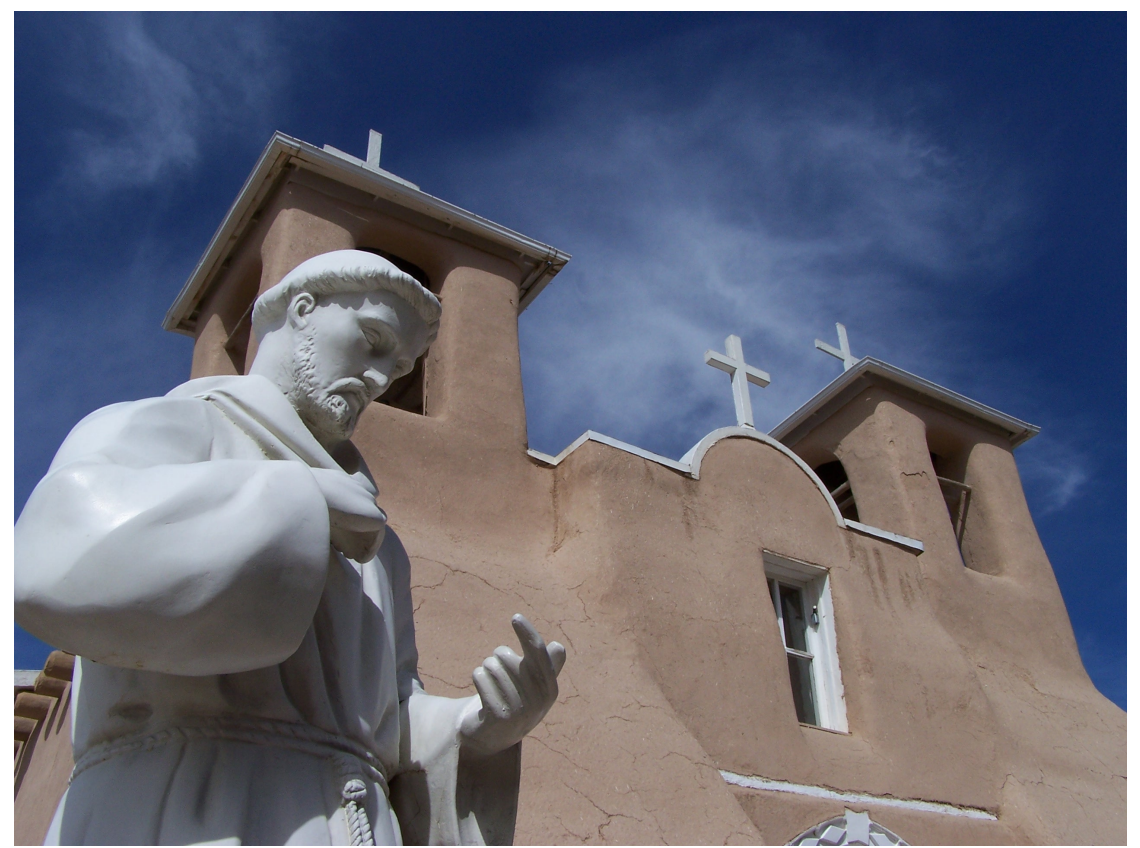

Figure 7: St. Francis Church in Ranchos de Taos, annually replastered by local Hispanic women. Photo: P. Mácha 2006.

\section{Spatial regimes}

The fourth principal factor in the establishment and maintenance of group boundaries refers to the differential spatial regimes which regulate access to public spaces and participation in public life. Group boundaries have a dual function - they exclude the Other and they discipline those who are included by threatening them with expulsion from the community in case of their non-conformity. Different spatial regimes are established within and outside group boundaries, regulating not only the flow of people and things across these boundaries but also the circulation and the activities of people inside them.

In many ways ethnic spatial regimes might be likened to Foucault's regimes of truth (see e.g. FOUCAULT 1977). They are also self-evident (through their internal logic and materiality), enabling (making it possible to acquire an ethnically defined subjectivity), disciplining (requiring all ethnic subjects to submit to the authority of the tribal representatives) and disabling (making certain ways of thinking, doing and making 
PŘEMYSL MÁCHA

Ethnicity in Space and Everyday Practice: an Outline of a General Framework with Examples from New Mexico

unthinkable and impossible). The regimes of (ethnic) truth are powerful spatial tools which significantly contribute to the internalization and naturalization of group boundaries.

Spatial regimes place limits on access, circulation and the capacity to act. All communities have to control their boundaries, otherwise they cease to exist. But they have a choice of criteria to be used. In New Mexico, more often than not, ethnic criteria are applied, especially in the case of indigenous and Hispanic communities. Ethnic spatial regimes thus become everyday reminders of ethnic loyalties and alterities.

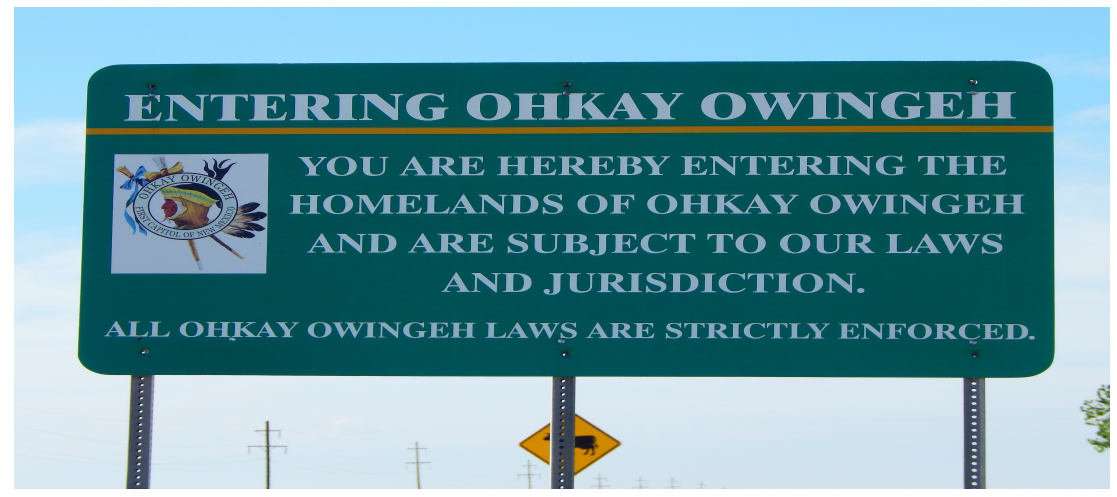

Figure 8: Signs as reminders of different ethnic spatial regimes. Photo: P. Mácha 2015.

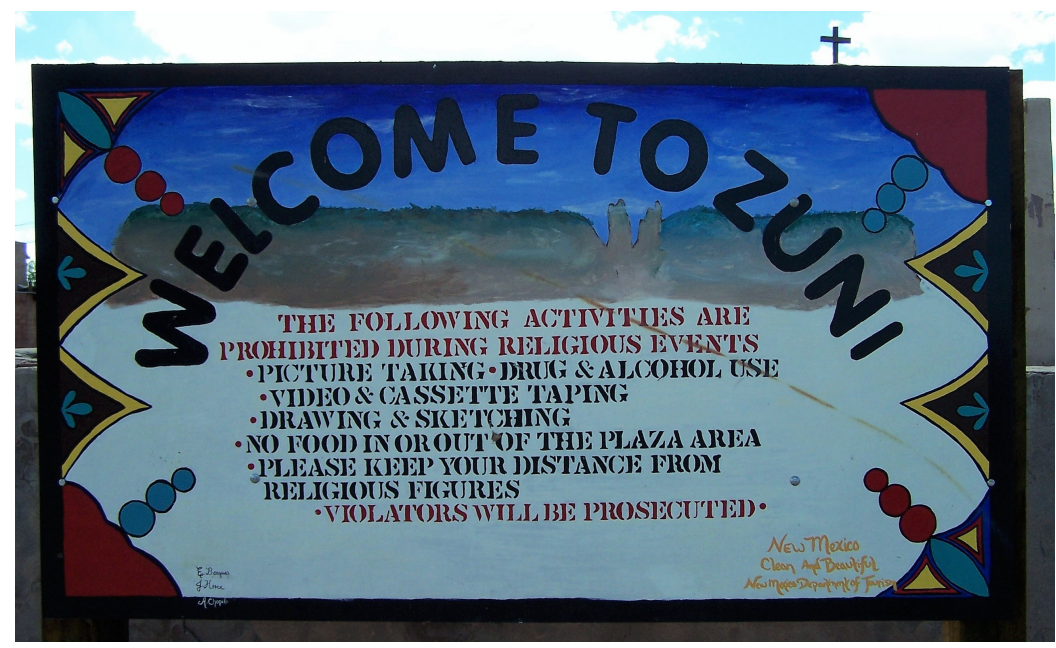

Figure 9: "Welcome” sign in Zuni Pueblo. Photo: P. Mácha 2015. 


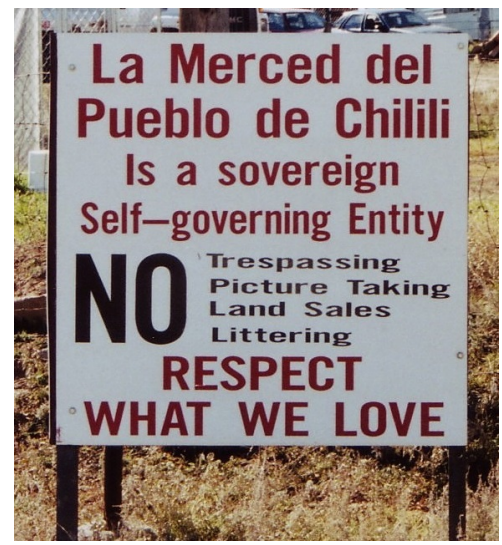

Figure 10: "Welcome" sign in the Hispanic village of Chililí. Photo: P. Mácha 2015.

The regulation of access determines who is allowed to enter. The most common unit of regulation is the community (village). Some communities in New Mexico have closed themselves off entirely and are effectively gated communities now (e.g. Pueblo of Santa Ana, Pueblo of Jemez). No outsider is allowed to enter. Other pueblos regulate access only on certain days of the year, usually during important ceremonial occasions. For example, the Pueblo of Taos closes down for the public during two months each spring. On such occasions, the access to the community is guarded by armed men. Still others charge visitors for entering (Pueblo of San Ildefonso) or allow entry only with a guide (Pueblo of Acoma). More commonly, however, entry itself is permitted or even encouraged (for commercial reasons) but limits are placed on the circulation within the community and permitted activities. Often parts of the community are off-limits because they are considered sacred. Frequently, photography is not permitted at all and such prohibitions can be found not only in most indigenous but also in some Hispanic communities (see MÁCHA 2013).

While spatial regulation at the community level is the most frequent, it occurs at different scales as well. In New Mexico, the tribal reservation borders for indigenous communities and land grant borders for Hispanic communities mark out spatial regimes on a larger scale while access to kivas, moradas and other public buildings is strictly limited on a lower scale. No hiking or photography by outsiders is allowed on Jemez reservation, for example, and trespassers would certainly meet harsh reactions on the Abiquiu or Chililí land grants. As in the previous cases, all scales influence each other and establish a complex set of 

from New Mexico

overlapping and sometimes conflicting spatial regimes which demand enforcement on the one hand (i.e. tribal police, informal social control) and codification and visibility on the other (local codes, signs, information leaflets, announced warnings).

Spatial regulation, however, is not limited to outsiders only. For example, while outsiders are prohibited from witnessing certain ceremonies, tribal members in all villages are required to participate even if they do not wish to. Participation is mandatory. The tribal elders of Taos and Acoma prohibited the use of electricity, in-door plumbing, water toilets and other amenities in the old village. If a Taos or Acoma woman marries an outsider, she loses tribal rights and is expelled from the community. The tribal leaders of Jemez Pueblo prohibited the writing of the Towa language to prevent outsiders from learning it. These are just a few examples of how spatial regimes work not only to exclude but also to discipline those who are included.

\section{Performance and embodied practice}

The fifth principal factor in the production and cementation of ethnic boundaries involves the embodied performances of ethnic difference which regularly structure peoples' lives. These include a range of practices, some of them every-day and ordinary, others occasional and special, all, however, involving the body as the locus of ethnicity in its movement through space. Ethnicity is done and made and in this doing and making, the body is fundamental both in its aspect as the actor as that which is acted upon, with and through. In contemporary geography and anthropology, the body is one of the crucial topics of research and by focusing on how social processes such as ethnicity are embodied, performed and experienced, we gain a greater insight into the nature of these processes than if we simply continued to treat them as disembodied concepts, ideologies, or discourses (see e.g. LONGHURTS 1997).

Embodied practices of ethnic character which most easily capture our attention are often spectacular religious or festive performances with wide publicity. In these traditions, ethnic difference is emphasized by movement, language, gestures, clothing, paraphernalia, humor, organization of the stage, and various spatial practices requiring intensive physical and spiritual preparation and bodily discipline. Hundreds of different ritual and festive performances take place in Native American, Hispanic and Anglo communities in New Mexico every year, constantly renewing faulting ethnic boundaries and revitalizing the ethnic space. Examples of these traditions include the Santa Fe Fiesta commemorating the "peaceful" reconquest of New Mexico by the Spanish in 1692, the Matachines dances in the 
Hispanic communities performed as a community binding and sanctifying event, the Comanche dances performed in the genizaro communities in the north of the state as a means of revitalizing cultural identity or the ancient harvest and winter dances of the Pueblos clearly delimiting group boundaries (see e.g. RODRÍGUEZ 1996; WILSON 1997; MÁCHA 2006; MÁCHA 2007).

Let us at least briefly describe two - the Santa Fe Fiesta and the Matachines Dance. The Santa Fe Fiesta is another powerful landscape practice invented as a means of fostering a common state identity and it is closely associated with the so-called Santa Fe art colony. It is a widely advertised and very popular tourist event which, however, serves primarily to sort out local ethnic relations. The fiesta takes place annually every September since 1919 when it was initiated by Anglos sympathetic to the Hispanic heritage who wanted to foster a common state identity. The organizers, however, present it as a centuries-old tradition, creating thus an illusion of antiquity and authenticity (for this historic mystification see the fiesta web site http://www.santafefiesta.org/). The fiesta celebrates the supposedly voluntary and mutually enriching fusion of three cultures - the Pueblo, the Hispanic and the Anglo. Its central performance is a parade going through the town and headed by Don Diego de Vargas, the Governor of New Mexico who led the "peaceful" reconquest of the colony in 1692 after the Spaniards were forced out from New Mexico during the Pueblo Revolt in 1680. It reenacts the moment of submission of Pueblo chiefs, impersonated initially by actual Pueblo members. Originally, the parade also included General Stephen W. Kearney who led U.S. troops to New Mexico in 1846, but this character was left out after the first few fiestas, leaving the central role to Vargas. Since its beginning, the fiesta has generated strong criticism for its historical incorrectness, inauthenticity and caricaturing of Pueblo and Hispanic inhabitants of New Mexico. For example, the Pueblo dancers prefer to present their own traditional dances and Native American characters in the pageant have to be impersonated by Hispanics and Anglos. Of late, due to the heavy immigration from Mexico, the fiesta has acquired a strongly Mexican character (in dress, music, and food) and because of its artificiality and debatable character, it is boycotted by many Puebloans as well as original Hispanic inhabitants of Santa Fe (for a full description of the history of the fiesta see WILSON 1997:181-231). Others, however, come and join in the celebrations and it is perhaps here that the illusion of a common state identity is forged after it turned out that the "authentic" traditions in Native American and Hispanic communities could not be tamed and harnessed for state purposes.

Another important performance is the Matachines Dance. This fascinating tradition is shared by many Hispanic and Pueblo communities throughout New Mexico and it goes well beyond the scope of this paper to describe the history, complex choreography and rich 

from New Mexico

meanings associated with the dance. The dance is one of the so-called Dances of Conquest (Danzas de la Conquista) which are thought to have been introduced into the New World by Spanish friars as a means of evangelization. Its central characters are Monarca (Montezuma), Malinche (Virgin Mary), Matachines proper (Montezuma's warriors), Abuelos/Clowns and the Bull. In Hispanic villages, the dance is generally interpreted as the celebration of the victory of Christianity symbolized by the conversion of Montezuma and the castration and killing of the Bull as the symbol of paganism. The meaning of the dance in Pueblo communities is somewhat less clear, but in both cases, as Rodriguez (1996) and we (MÁCHA 2006) have demonstrated, this dance serves as a crucial factor in the delimitation and reproduction of ethnic boundaries. The dancers go around the village, purify it from (ethnic) defilement and perform a final dance of victory next to the old adobe church in the vicinity of the old cemetery, that is, for the ancestors. Clowns who are the most complex of the many characters involved in the dance crack jokes all throughout the performance, many of them with fundamental ethnic overtones. Both the Santa Fe Fiesta and the Matachines Dance draw and reinforce ethnic boundaries and renew ethnic loyalties.

Important as these spectacles may be, there are also the perhaps less visible but equally important everyday bodily practices through which ethnicity is made present in peoples' ordinary lives. This includes dialect, non-verbal communication, posture, movement, jewelry, clothing, habitual activities along ethnically defined routes and in ethnically defined ways (such as irrigating fields in Hispanic communities), making of ethnic art (very common source of income for indigenous families), etc. Bodily rapport is usually established before the verbal one and affect (THRIFT 2007) and emotion (including ethnic belonging) is often communicated non-verbally. The everyday performance of ethnic difference is omnipresent and it becomes a constant flow of spatial practices associated with things and places which afford them their relative stability over time. Our bodies are cultural products, as Babcock (1994) showed for Pueblo women, and without them any study of ethnicity would be incomplete. 
PŘEMYSL MÁCHA

Ethnicity in Space and Everyday Practice: an Outline of a General Framework with Examples from New Mexico

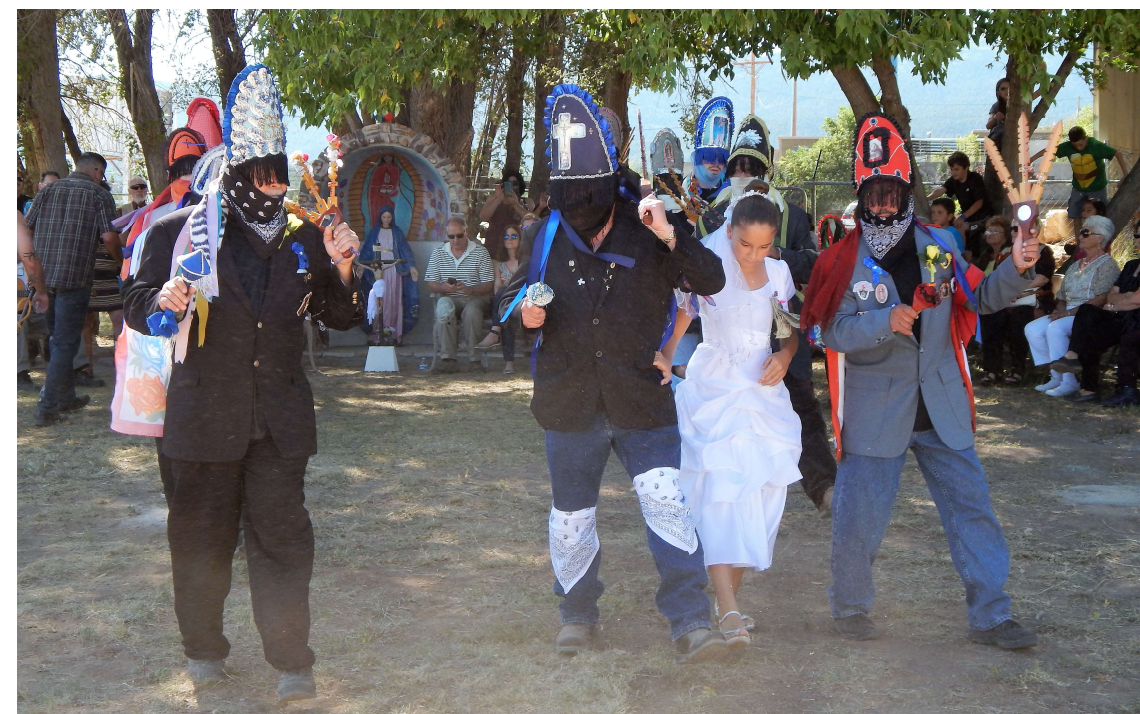

Figure 11: Malinche (Virgen), Monarca (Montezuma) and his soldiers perform the Matachines Dance for the Hispanic community of San Antonito. Photo: P. Mácha 2015.

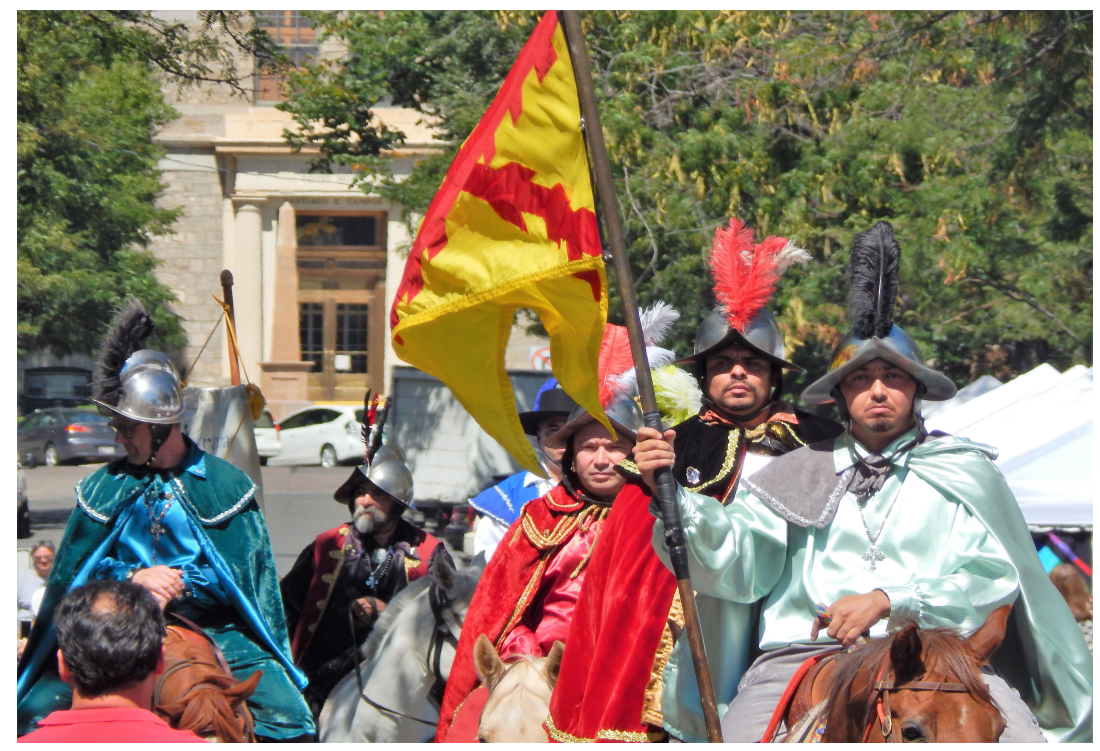

Figure 12: Diego de Vargas and his soldiers arrive to "peacefully" reconquer New Mexico during the Santa Fe Fiesta. Photo: P. Mácha 2015. 


\section{Language and ethnic space}

The last strategy of ethnic boundary making that I would like to comment on is the linguistic appropriation, delimitation, and signification of space through signs and place names. As the classical cultural geographer Yi-Fu Tuan (1991: 688) showed:

"Naming is power - the creative power to call something into being, to render the invisible visible, to impart a certain character to things."

Language is not innocent and it wields an immense power over our perception and interpretation of the world. Even though language lacks a direct material quality, it is unthinkable without physicality, making itself tangible through a number of material manifestations, including bodies, things, and places. And what is important for us here is the fact that language is always and inextricably bound with space - it is a spatial phenomenon and its spatial situatedness, specific embodiments and performances give it its full meaning (SCOLLON - SCOLON 2003).

When speaking of ethnicity in space, the choice of the preferred linguistic code (be it language or dialect) is naturally the most important and linguistic control is part of many of the spatial regimes and embodied practices mentioned above. Indigenous languages are strong boundary making factors but so are the dialects of English used in indigenous communities which differ from standard English. Equally important is the use of New Mexican Spanish which conserves elements of ancient Spanish grammar and vocabulary as a way to differentiate local Hispanics from the new coming Mexicans and other Latin Americans while "Spanglish" (i.e. a dialect of English used in Hispanic communities) clearly indicates the ethnicity of the speaker vis-à-vis the Anglos. The ethnic sociolinguistics of New Mexico is complex and crucial for ethnic boundary maintenance (for Spanish see e.g. BILLS - NEDDY 2008; for Pueblo languages e.g. SIMS 2008).

Regardless of the choice of the linguistic code, there are words which are to an extent independent of the language in which they were coined and they enter freely into other languages. The most important linguistic aspect in relation to space undoubtedly is the proper name of a place - the place name or a toponym. Place names carry political messages, memories and emotions and serve as tools for claiming territory, place-making, grounding one's identity, and establishing a home (see e.g. BASSO 1996; JETT 1997; KEARNS - BERG 2002; BERG - VUOLTEENAHO 2009; ROSE-REDWOOD ALDERMAN - AZARYAHU 2010; RADDING - WESTERN 2010). While personal attachments to place are very important (see e.g. KEARNYE - BRADLEY 2009), there is also a significant political component to place naming whereby place names may be used, 

from New Mexico

for example, to erase linguistic traces of original populations, gain political legitimacy, delegitimize other political forces, naturalize certain versions of history and silence dissent. This is possible because of place names'

"ability to incorporate an official version of history into such spheres of human activity that seems to be entirely devoid of direct political manipulation. This transforms history into a feature of the 'natural order of things' and conceals its contrived character" (AZARYAHU 1997:481).

What holds true for the built environment holds true for place naming as well. The general relationship between place names and power can be fruitfully applied to ethnic relations, ethnic boundary making and the legitimization of ethnic spatial regimes in the ethnic landscape.

Ethnically defined place names can be used to mark out the ethnic space in the same way that fences and border stones can, both mentally in everyday conversations and official documents but also physically in the form of road signs, street signs, information panels and other texts in the linguistic landscape. They can serve as grounds for justifying legal claims to land, water rights and land use. They can remind users of their ethnic membership and express it and they can also serve as a tool for asserting group identity. All of these strategies can be observed in many cases in the ethnic landscape of New Mexico.

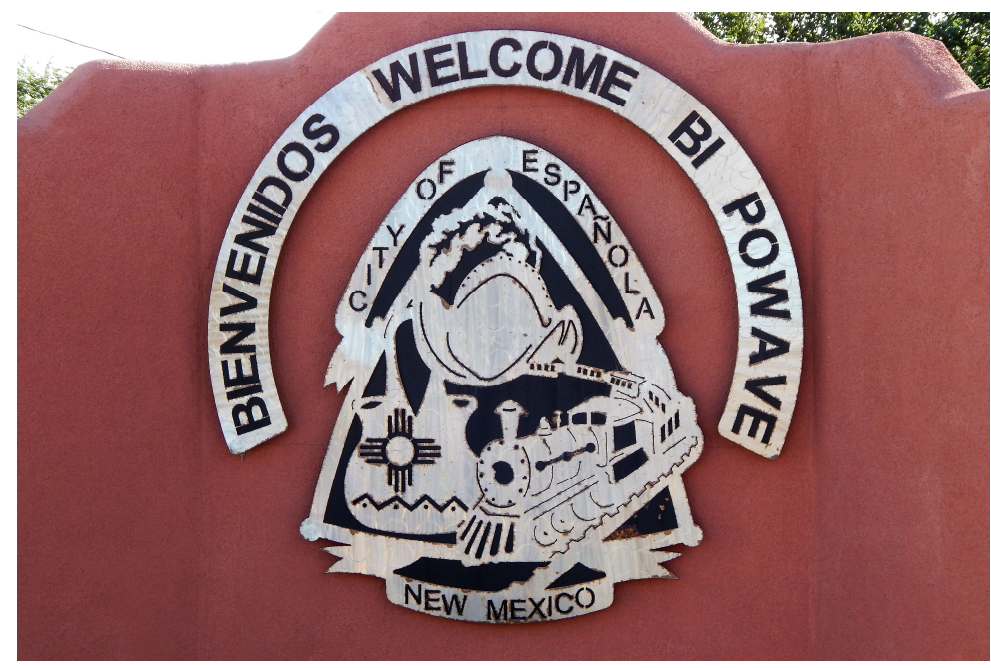

Figure 13: Trilingual linguistic landscape of the Hispanic town of Española. Photo: P. Mácha 2015. 
PŘEMYSL MÁCHA

Ethnicity in Space and Everyday Practice: an Outline of a General Framework with Examples from New Mexico

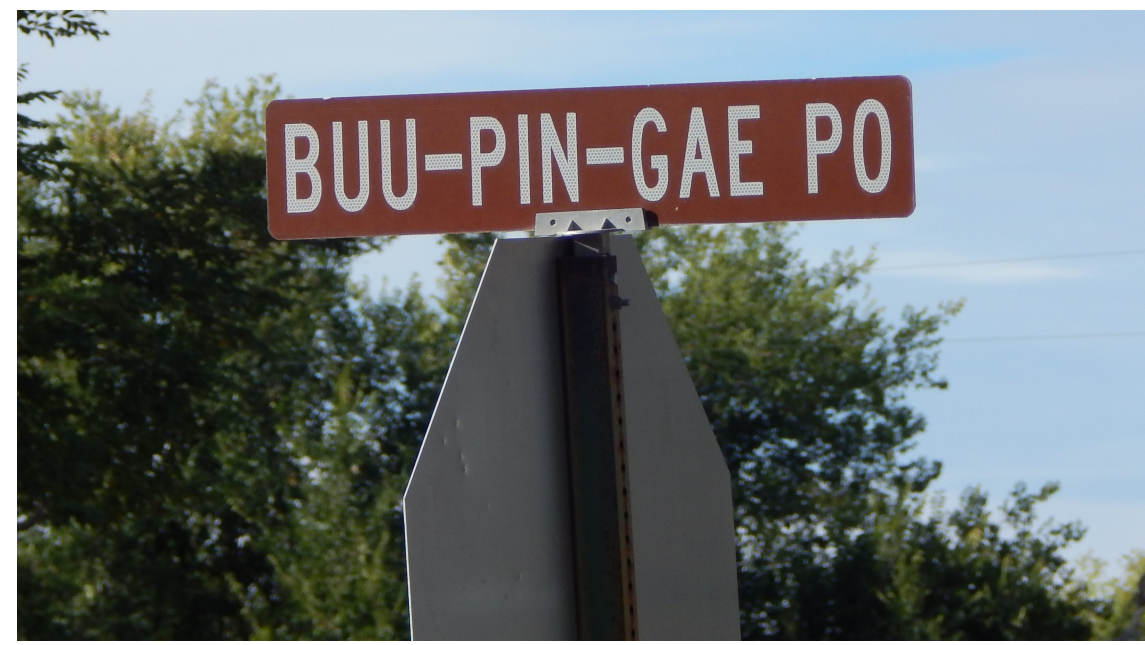

Figure 14: Street sign in the Tewa-speaking San Ildefonso Pueblo. Photo: P. Mácha 2015.

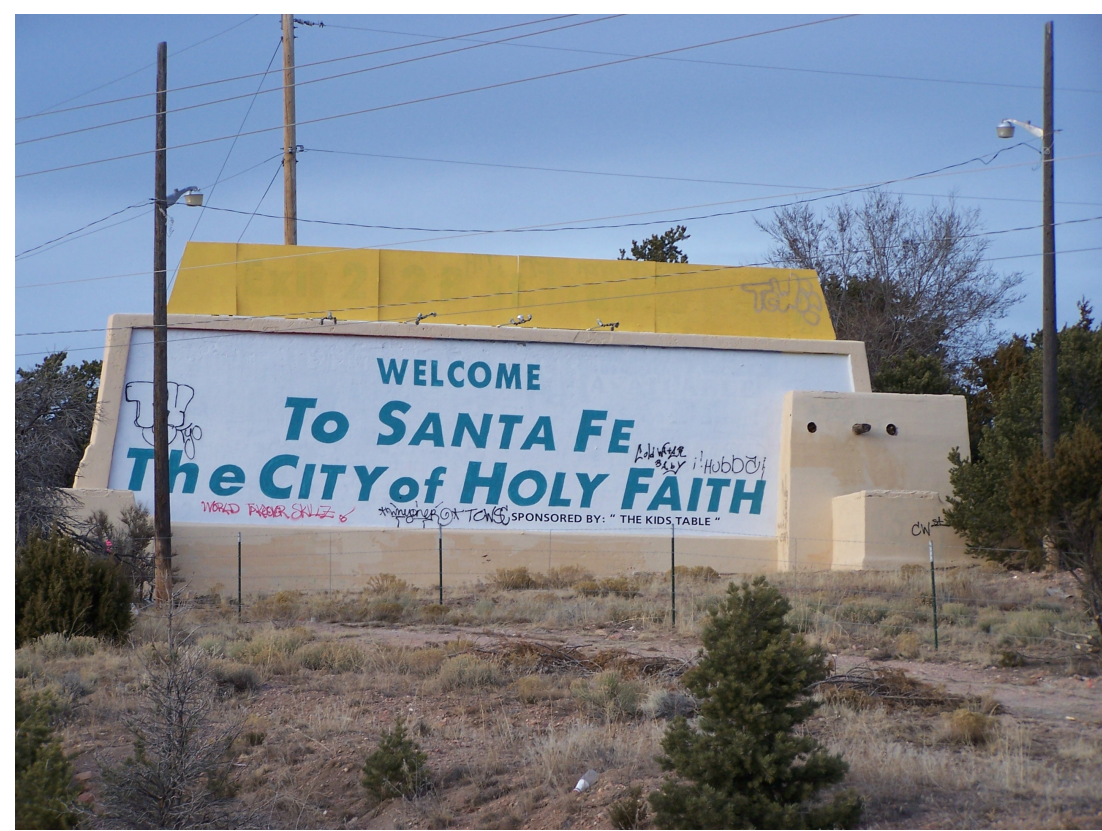

Figure 15: Linguistic reminder of the Hispanic and Catholic origin of Santa Fe. Photo: P. Mácha 2006. 

from New Mexico

In terms of the self-assertion of group identity, several indigenous communities have decided to cast away their Spanish names and return to their original ones. The best known example is the renaming of San Juan Pueblo to Ohkay Owingeh in 2005, but other pueblos are gradually following suit. For example, Santo Domingo Pueblo, a very conservative Keres-speaking community, is currently promoting the official use of its original name Kewa. Other pueblos such as Nambé, Acoma or Taos preserve their original names and guard them jealously against appropriation by other groups.

For example, in 2014, the representatives of Taos Pueblo objected to the decision of the Taos city council to rename Kit Karson Park to Red Willow Park (see e.g. SIMONICH 2014). Kit Karson was a controversial figure implicated, among other things, in the capture and internment of Navahos and Apaches in the Bosque Redondo reservation in 1860s, so one might think the indigenous people would welcome the erasure of his name from the toponymic landscape. However, Taos Pueblo representatives felt that it was even more important to retain exclusive control over their traditional name which in the Tiwa language spoken in Taos Pueblo means "The Place of Red Willows". As of April 2016, the park's name continues to be Kit Karson Park.

Struggles for linguistic representation in the ethnic landscape are not unique to indigenous communities. For example, the Hispanic village of San Antonito in East Mountains threatened by the mostly Anglo suburbanization processes of Albuquerque fought hard against the new name of Sandia Park and, after several years, the original Hispanic name was finally returned to official use and reappeared on maps and road signs. I also registered strong toponymic sentiments in the traditional, land-grant genízaro village of Abiquiu where local Spanish-speaking inhabitants felt that the name of their home had been highjacked by Anglo entrepreneurs who turned it into a commercial brand for the sale of art products and real estate outside of the village.

Place names are also used as grounds for claiming territory and right of use. For example, the representatives of Jemez Pueblo have begun to emphasize ancestral rights to the Jemez Mountains (named after the pueblo) and they make this claim visible in the linguistic landscape (see photograph). Similarly, much debates have surrounded claims of ownership of sacred places such as Chimayó, the most important catholic pilgrimage site in New Mexico which, nevertheless, still is also a very important sacred place for many of the Tewa-speaking pueblos who gave the hill its name - Tsi Mayoh. Sandia Mountains, called Okuu Pin (Turtle Mountain) by the Tewa-speaking pueblos, are another point of contention, especially for the Sandia and Isleta pueblos which consider it their principal sacred mountain 
Finally, place names are used to ethnicize the communal space and make ethnic identity present in the everyday life. Names are placed on signs and written on built structures such as buildings or bridges to be visible reminders of ethnic boundaries. Some pueblos implemented street names in the local language. In San Ildefonso, for example, we find Tewa street names such as Than Povi Po, Odo Po and Povi Kaa Dr. Others such as Santa Clara use English names but with an indigenous connotation such as Two Waters Meet Rd., Water's Edge Rd. or Eagle Rd. Hispanic and Anglo towns do the same and so, for example, in Española we find street names in Spanish (Calle Vigil, Calle Amado) and names with great symbolic meaning such as Coronado Ave. ${ }^{5}$ Such names can be found also, for example, in Santa Fe, the capital of New Mexico and originally a Hispanic town, where one of the streets in the old center is called De Vargas St., named after the Spanish governor who led the reconquest of New Mexico in 1692. Interestingly, both towns have streets named after Montezuma, the Aztec emperor, whereby they declare Mexican (indigenous) heritage. No streets carry the names of local indigenous leaders, though. In Anglo towns such as Portales in eastern New Mexico we find street names such as Austin Ave., Abilene Ave. and Dallas Ave. which not only express Anglo identity but also memories of the historic conflict between Texas and New Mexico over this part of the state.

Place names thus give another layer to spatial perception, interpretation and performance and serve as stabilizing mechanisms for ethnic boundaries, just as physical structures do. Place names are a very conservative element in the landscape and even though new political regimes seek to change toponymy to legitimize themselves, old place names remain in everyday use and naturalize earlier social orders of which ethnic relations form an integral part. Because of their material manifestation, place names, together with more general linguistic codes, form the basis of the linguistic landscape which is a useful concept for the analysis of the linguistic dimension of ethnic landscapes (see e.g. essays in SHOHAMY - GORTER 2009).

\section{Conclusion}

To conclude, we can say that ethnicity is a complex socio-spatial phenomenon that cannot be reduced to simple social interaction. Material, performative, linguistic, and spatial practices contribute significantly to the formation and stabilization of ethnic boundaries.

5 Francisco de Coronado was a conquistador who led the first organized Spanish expedition into New Mexico in 1540. Among indigenous people he is remembered for his exceptional cruelty. 
Without taking them into consideration it would be impossible to explain the persistence or the current revitalization of group identities without falling back to primordialism and essentialism. Borders and spatial separation, the built environment and the processes associated with its production and maintenance, spatial regimes, embodied practices and performances, and the linguistic landscape are the crucial factors in the construction and internalization of ethnic landscapes. Conscious and unconscious, voluntary and coerced, occasional and habitual, every-day doings and makings keep ethnic landscapes alive and structure our lives through them, making them appear as natural, inevitable, and impossible or even damaging and threatening to alter. Much has yet to be learned about ethnicity in space but a systematic approach to this topic along the lines suggested in this article may not only help us understand better how ethnic identities function spatially but also, and more importantly, can offer ways of reducing the relevance of ethnicity in everyday social relations and contribute to the moderation of ethnic conflicts. The challenge in front of us, to paraphrase one of Ingold's essays (2008), therefore is building against boundaries.

\section{Bibliography}

AMOORE, L. (2006): Biometric Borders: Governing Mobilities in the War on Terror. Political Geography Vol. 25, No. 3, pp. 336-351.

ALVAREZ, R. (2012): Borders and Bridges: Exploring a New Conceptual Architecture for (US-Mexico) Border Studies. The Journal of Latin American and Caribbean Anthropology Vol. 17, No. 1, pp. 24-40.

ASH, J. - SIMPSON, P. (2016): Geography and Post-Phenomenology. Progress in Human Geography Vol. 40, No. 1, pp. 48-66.

AZARYAHU, M. (1997): German Reunification and the Politics of Street Names: The Case of East Berlin. Political Geography Vol. 16, No. 6, pp. 479-493.

BABCOCK, B. A. (1994): Pueblo Cultural Bodies. Journal of American Folklore Vol. 107, No. 423, pp. 40-54.

BARTH, F. (1969): Introduction. In Fredrik Barth (ed.) Ethnic Groups and Boundaries. The Social Organization of Cultural Difference. Boston, MA: Little, Brown and Co., pp. 9-38.

BASSO, K. H. (1996): Wisdom Sits in Places. Landscape and Language among the Western Apache. Albuquerque, NM: University of New Mexico Press. 
BERG, L. D. - VUOLTEENAHO, J. (eds.) (2009): Critical Toponymies: The Contested Politics of Place Naming. Farnham: Ashgate Publishing, Ltd.

BILLS, G. D. - NEDDY, A. V. (2008): The Spanish Language of New Mexico and Southern Colorado: A Linguistic Atlas. Albuquerque, NM: University of New Mexico Press.

BROOKS, J. F. (2011): Captives and Cousins: Slavery, Kinship, and Community in the Southwest Borderlands. Chapell Hill, NC: University of North Carolina Press Books.

BRUBAKER, R. (2004): Ethnicity without groups. Cambridge, MA: Harvard University Press.

BUNTING, B. (1976): Early Architecture in New Mexico. Albuquerque, NM: University of New Mexico Press.

CORREIA, D. (2013): Properties of Violence: Law and Land Grant Struggle in Northern New Mexico. Athens, GA: University of Georgia Press.

DOVEY, K. (1999): Framing Places: Mediating Power in Built Form. New York: Routledge.

DUNBAR-ORTIZ, R. (2007): Roots of Resistance: Land Tenure in New Mexico. Norman, OK: University of Oklahoma Press.

DURÁN, C. (2007): Panaderías, peluquerías, y carnicerías: Re-Mexicanizing the Urban Landscapes of a Southwest City. Ph.D. Dissertation, University of New Mexico.

ERIKSEN, T. H. (2002): Ethnicity and Nationalism. London: Pluto Press.

FOUCAULT, M. (1977): Discipline and Punish: The Birth of the Prison. New York: Vintage.

GONZALES, M. (2014): The Genizaro Land Grant Settlements of New Mexico. Journal of the Southwest Vol. 56, No. 4, pp. 583-602.

HOOKER, V. D. (2000): Only in New Mexico: An architectural history of the University of New Mexico. Albuquerque, NM: University of New Mexico Press.

INGOLD, T. (2008): Bindings against boundaries: entanglements of life in an open world. Environment and planning A 40.8, pp. 1796-1810.

INGOLD, T. (2011): Being Alive: Essays on Movement, Knowledge and Description. London and New York: Routledge.

INGOLD, T. (2015): The Life of Lines. London and New York: Routledge.

IOWA, J. (1985): Ageless Adobe: History and Preservation in Southwestern Architecture. Santa Fe, NM: Sunstone Press.

DOI: 10.1515/eas-2017-0007 C University of SS. Cyril and Methodius in Trnava. All rights reserved. 
JACKSON, J. B. (1985): The Essential Landscape: The New Mexico Photographic Survey. Albuquerque, NM: University of New Mexico Press.

JETT, S. C. (1997): Place-Naming, Environment, and Perception among the Canyon de Chelly Navajo of Arizona. The Professional Geographer Vol. 49, No. 4, pp. 481 493.

JOHN, E. A. H. (1996): Storms Brewed in Other Men's Worlds: The Confrontation of Indians, Spanish, and French in the Southwest, 1540-1795. Norman, OK: University of Oklahoma Press.

JOHN, R. St. (2011): Line in the Sand: A History of the Western US-Mexico Border. Princeton, NJ: Princeton University Press.

KARAIM, R. (2015): It Takes a Village. The Future of a New Mexico Pueblo Can Be Found in Its Past. Preservation Vol. 67, No. 1, pp. 26-33.

KEARNEY, A. - BRADLEY, J. J. (2009): 'Too Strong to Ever not Be There': Place Names and Emotional Geographies. Social \& Cultural Geography Vol. 10, No. 1, pp. 77-94.

KEARNS, R. A. - BERG, L. D. (2002): Proclaiming Place: Towards a Geography of Place Name Pronunciation. Social \& Cultural Geography Vol. 3, No. 3, pp. 283-302.

KESSELL, J. L. (2013): Spain in the Southwest: A narrative history of colonial New Mexico, Arizona, Texas, and California. Norman, OK: University of Oklahoma Press.

KRINSKY, C. H. (1996): Contemporary Native American Architecture: Cultural Regeneration and Creativity. Oxford: Oxford University Press.

LATOUR, B. (2005): Reassembling the Social: An Introduction to Actor-Network Theory. Oxford: Oxford University Press.

LONGHURST, R. (1997): (Dis) Embodied Geographies. Progress in Human Geography Vol. 21, No. 4, pp. 486-501.

MÁCHA, P. (2006): Los Matachines. Identita a politika v Novém Mexiku na príkladu tance. Český lid Vol. 93, No. 2, pp. 179-198.

MÁCHA, P. (2007): Los Comanches de Nuevo México. Hybridita, autenticita a politika identity v Novém Mexiku. Český lid Vol. 94, No. 2, pp. 141-156.

MÁCHA, P. (2013): Resistance through Tourism: Identity, Imagery, and Tourism Marketing in New Mexico. Joao Sarmento - Eduardo Brito-Henriques (eds.) Tourism in the Global South: Heritages, Identities and Development. Lisabon: University of Lisbon, Centre for Geographical Studies, pp. 91-112. 
MALNAR, J. M. - VODVARKA, F. (2013): New architecture on indigenous lands. Minneapolis, MN: University of Minnesota Press.

MARKOVICH, N. C., - PREISER, W. F. E. - STURM, F. G. (eds.) (1990): Pueblo Style and Regional Architecture. New York: Van Nostrand Reinhold.

MASSEY, D. (2007): For Space. London: Sage Publications Ltd.

McDowell, Linda. Gender, Identity and Place. Cambridge: Polity 1999.

MEINIG, D. W. (1971): Southwest: Three peoples in geographical change, 1600-1970. New York: Oxford University Press.

MORROW, B. H. - PRICE, V. B. (eds.) (1997): Anasazi Architecture and American Design. Albuquerque, NM: University of New Mexico Press.

NEWMAN, D. - PAASI, A. (1998): Fences and Neighbours in the Postmodern World: Boundary Narratives in Political Geography. Progress in Human Geography Vol. 22, No. 2, pp. 186-207.

NOSTRAND, R. L. (1996): The Hispano Homeland. Norman, OK: University of Oklahoma Press.

PRESCOTT, J. R. V. (2014): Political Frontiers and Boundaries. New York: Routledge.

RADDING, L. - WESTERN, J. (2010): What's in A Name? Linguistics, Geography, and Toponyms. Geographical Review Vol. 100, No. 3, pp. 394-412.

RESÉNDEZ, A. (2005): Changing National Identities at the Frontier: Texas and New Mexico, 1800-1850. Cambridge: Cambridge University Press.

RIVERA, J. (1999): Acequia Culture: Land, Water, and Community in the Southwest. Albuquerque, NM: University of New Mexico Press.

RODRÍGUEZ, S. (1996): The Matachines Dance: Ritual Symbolism and Interethnic Relations in the Rio Grande Valley. Albuquerque, NM: University of New Mexico Press.

RODRÍGUEZ, S. (2006): Acequia: Water-Sharing, Sanctity, and Place. Santa Fe, NM: School for Advanced Research Press.

ROMERO, F. (2008): Hyperborder: The Contemporary US - Mexico Border and It's Future. Princenton, NJ: Princeton Architectural Press.

ROSE-REDWOOD, R. - ALDERMAN, D. - AZARYAHU, M. (2010): Geographies of Toponymic Inscription: New Directions in Critical Place-Name Studies. Progress in Human Geography Vol. 34, No. 4, pp. 453-470. 
SCOLLON, R. - WONG SCOLLON, S. (2003): Discourses in Place. Language in the Material World. London and New York: Routledge.

SCULLY, V. (1989): Pueblo: Mountain, Village, Dance. Chicago, IL: University of Chicago Press.

SHOHAMY, E. - GORTER, D. (eds.) (2009): Linguistic Landscape: Expanding the Scenery. New York and London: Routledge.

SIMONICH, M. (2014): Taos Park Named Again for Kit Karson, for Now. Santa Fe New Mexican July 8, 2014, available on-line at: http://www.santafenewmexican.com/news/local_news/ taos-park-again-named-for-kitcarson-for-now/article_18f0f3d9-e0ed-55c7-b36a-1ab359d2e454.html

SIMS, C. (2008): Assessing the Language Proficiency of Tribal Heritage Language Learners: Issues and Concerns for American Indian Pueblo Languages. Current Issues in Language Planning Vol. 9, No. 3, pp. 327-343.

THRIFT, N. (2007): Non-Representation Theory. Space, Politics, Affect. London and New York: Routledge.

TUAN, Y. F. (1991): Language and the Making of Place: A Narrative-Descriptive Approach. Annals of the Association of American Geographers Vol. 81, No. 4, pp. 684696

VAN HOUTUM, H. - KRAMSCH, O. T. - ZIERHOFER, W. (eds.) (2005): B/ordering Space. Aldershot: Ashgate.

WEBER, D. J. (2003): Foreigners in Their Native Land: Historical Roots of the Mexican Americans. Albuquerque, NM: University of New Mexico Press.

WILSON, C. M. (1997): The Myth of Santa Fe: Creating a Modern Regional Tradition. Albuquerque, NM: University of New Mexico Press.

WILSON, C. M. - POLYZOIDES, S. (eds.) (2011): The Plazas of New Mexico. San Antonio, TX: Trinity University Press. 